\title{
Corn silage hybrid type and quality of alfalfa hay affect dietary nitrogen utilization by early lactating dairy cows ${ }^{1}$
}

\author{
M. S. Holt, ${ }^{\star}$ K. Neal, ${ }^{\star}$ J.-S. Eun, ${ }^{\star 2}$ A. J. Young, ${ }^{\star}$ J. O. Hall, ${ }^{*}$ and K. E. Nestor Jr.† \\ *Department of Animal, Dairy, and Veterinary Sciences, Utah State University, Logan 84322 \\ †Mycogen Seeds, Indianapolis, IN 46268
}

\begin{abstract}
This experiment was conducted to determine the effects of corn silage (CS) hybrids and quality of alfalfa hay $(\mathrm{AH})$ in high-forage dairy diets on $\mathrm{N}$ utilization, ruminal fermentation, and lactational performance by early-lactating dairy cows. Eight multiparous Holstein cows were used in a duplicated $4 \times 4$ Latin square experiment with a $2 \times 2$ factorial arrangement of dietary treatments. The 8 cows (average days in milk $=23 \pm$ 11.2 ) were surgically fitted with ruminal cannula, and the 2 squares were conducted simultaneously. Within square, cows were randomly assigned to a sequence of 4 diets: conventional CS (CCS) or brown midrib CS (BMR) was combined with fair-quality AH [FAH: $46.7 \%$ neutral detergent fiber (NDF) and $18.4 \%$ crude protein $(\mathrm{CP})$ ] or high-quality $\mathrm{AH}$ (HAH: $39.2 \% \mathrm{NDF}$ and $20.7 \% \mathrm{CP}$ ) to form 4 treatments: CCS with FAH, CCS with HAH, BMR with FAH, and BMR with HAH. Diets were isonitrogenous across treatments, averaging 15.9\% CP. Each period lasted a total of $21 \mathrm{~d}$, with 14 $\mathrm{d}$ for treatment adaptation and $7 \mathrm{~d}$ for data collection and sampling. Intake of DM and milk yield did not differ in response to CS hybrids or $\mathrm{AH}$ quality. Although feeding BMR-based diets decreased urinary $\mathrm{N}$ output by $24 \%$, it did not affect fecal $\mathrm{N}$ output. Feeding HAH decreased urinary N output by $15 \%$ but increased fecal $\mathrm{N}$ output by $20 \%$. Nitrogen efficiency [milk N (g/d)/intake N (g/d)] tended to increase for BMR treatments. Ruminal ammonia- $\mathrm{N}$ concentration was lower for cows fed BMR-based diets than for those fed CCS-based diets but was not affected by quality of AH. Feeding BMR-based diets or $\mathrm{HAH}$ decreased milk urea N concentration by 23 or $15 \%$, respectively, compared with CCS-based diets or FAH. Total volatile fatty acid concentration increased with $\mathrm{HAH}$ but was not influenced by CS hybrids. Feeding BMR-based
\end{abstract}

\footnotetext{
Received February 12, 2013.

Accepted July 4, 2013.

${ }^{1}$ Approved as Journal Paper Number 8526 of the Utah Agricultural Experiment Station, Utah State University, Logan.

${ }^{2}$ Corresponding author: jseun@usu.edu
}

diets decreased urinary $\mathrm{N}$-to-fecal $\mathrm{N}$ ratio (UN:FN), and it was further reduced by feeding HAH. Although cows fed the BMR-based diets tended to increase milk N-to-manure $\mathrm{N}$ ratio, the quality of $\mathrm{AH}$ did not affect the ratio. The lower ratio of UN:FN with a higher ratio of milk N-to-manure $\mathrm{N}$ ratio for the BMR-based diets indicates that feeding BMR may reduce manure ammonia- $\mathrm{N}$ by reducing excretion of urinary $\mathrm{N}$ and increasing secretion of milk $\mathrm{N}$ per unit of manure $\mathrm{N}$ excreted.

Key words: dairy cow, brown midrib corn silage, alfalfa hay, nitrogen excretion

\section{INTRODUCTION}

A major emphasis has been placed on feeding less dietary $\mathrm{CP}$ to high-producing dairy cattle for 2 primary reasons. One is to improve profitability by increasing the efficiency of converting feed $\mathrm{N}$ intake to milk $\mathrm{N}$ output while maintaining overall milk production. The other is that feeding diets lower in CP decreases the excretion of $\mathrm{N}$ to the environment and consequently lowers ammonia $\left(\mathrm{NH}_{3}\right)$ emissions (Weiss, 2004). Olmos Colmenero and Broderick (2006) reported that diets containing $16.5 \% \mathrm{CP}$ were sufficient for maximizing production of milk and milk protein in dairy cows with minimal $\mathrm{N}$ excretion to the environment compared with diets with higher $\mathrm{CP}$ concentration. It is well established that, as the $\mathrm{CP}$ concentration of the diet increases, the amount of protein degraded in the rumen also increases (Olmos Colmenero and Broderick, 2006). Losses of dietary $\mathrm{N}$ can be reduced by decreasing protein degradation in the rumen or by increasing $\mathrm{N}$ use by ruminal microorganisms. Under typical dairy cattle feeding conditions, manipulation of RDP or the efficiency of $\mathrm{N}$ use in the rumen is the most effective strategy to reduce $\mathrm{N}$ losses (Tamminga, 1996).

Various chemical and physical dietary factors can affect ruminal fermentation and, consequently, $\mathrm{N}$ efficiency and milk production. Overall intake of $\mathrm{N}$ influences the amount of $\mathrm{N}$ excreted via manure, whereas types of carbohydrate and forage have greater effects on the route (fecal or urinary) of excretion (Wattiaux and Karg, 2004). The 2 most common forages fed to 
dairy cows in the United States are alfalfa and corn silage (CS); they complement each other by providing available $\mathrm{N}$ and fermentable energy for microbial $\mathrm{CP}$ synthesis in the rumen, respectively. In general, alfalfa is low in fiber and high in $\mathrm{CP}$, and it degrades rapidly and extensively in the rumen compared with other forages (Martin et al., 2004). Efficiency of $\mathrm{N}$ use in alfalfa silage-based diets is relatively low (Castillo et al., 2001) because of the high concentration of RDP (Nagel and Broderick, 1992). Due to the fermentation process, alfalfa silage contains more NPN than alfalfa hay $(\mathbf{A H} ; 52$ vs. 10\%, respectively; Martin et al., 2004). Conversely, CS is rich in starch and thus provides a key source of fermentable energy to the rumen microbial population. Corn silage made from brown midrib hybrids typically has higher OM degraded in the rumen and increases flow of microbial $\mathrm{N}$ to the small intestines, without affecting total-tract apparent digestibility (Oba and Allen, 2000). Because of lower feed intake but higher milk production in early lactation, nutrient utilization by dairy cows is particularly critical in this lactation phase to achieve potential production of dairy cows with a reduction in nutrient excretion. Thus, the current lactation study was performed to investigate our hypothesis that feeding dairy cows in early lactation a $16 \% \mathrm{CP}$ diet with fair-quality $\mathrm{AH}(\mathbf{F A H})$ in brown midrib CS (BMR)-based diets would maintain milk production, reduce urinary $\mathrm{N}$ excretion, and improve $\mathrm{N}$ efficiency compared with those fed high-quality $\mathrm{AH}(\mathbf{H A H})$ in conventional CS (CCS)- or BMR-based diets. We envisioned that overall effects of the combinations of main dairy forages could demonstrate a significant contribution of forages to nutrient utilization and management and might be used to formulate optimal dairy rations with relatively high forage concentrations to improve environmental performance of lactating dairy cows.

\section{MATERIALS AND METHODS}

The dairy cows used in this study were cared for according to the Live Animal Use in Research Guidelines of the Institutional Animal Care and Use Committee at Utah State University (approved protocol number: 1436). The study was conducted at the Caine Dairy Research Center, Utah State University (Wellsville) from February to June 2011.

\section{Cows, Experimental Design, and Diets}

Eight multiparous lactating Holstein cows surgically fitted with ruminal cannula were used. Days in milk averaged $23 \pm 11.2$ at the start of the experiment. Average BW was $639 \pm 53.6 \mathrm{~kg}$ at the beginning of the experiment and $649 \pm 42.2 \mathrm{~kg}$ at the end of the experiment.

The design of the experiment was a double $4 \times 4$ Latin square. Within each square, cows were randomly assigned to a sequence of 4 diets during each of the four 21-d periods (14 d of treatment adaptation and 7 $\mathrm{d}$ of data collection and sampling). A $2 \times 2$ factorial arrangement was used: CCS or BMR was combined with FAH $(46.7 \%$ NDF and $18.4 \% \mathrm{CP})$ or HAH $(39.2 \%$ NDF and $20.7 \%$ CP; Table 1) to form 4 treatments: CCS with FAH, CCS with HAH, BMR with FAH, and BMR with HAH (Table 2). Diets were isonitrogenous across treatments, averaging $15.9 \% \mathrm{CP}$. Diets are typical of high-producing dairy cows in the Intermountain West (i.e., Utah, Idaho, Wyoming, Montana, and parts of Arizona and Nevada) with $42 \%$ of the forage DM coming from AH.

Two CS hybrids, brown midrib corn hybrid (Mycogen F2F569, Mycogen Seeds, Indianapolis, IN) and conventional corn hybrid (DeKalb DKC61-72, Monsanto Com-

Table 1. Chemical composition (means $\pm \mathrm{SD}$ ) of forages $(\mathrm{n}=4$ sample replicates)

\begin{tabular}{|c|c|c|c|c|}
\hline \multirow{2}{*}{$\begin{array}{l}\text { Item, } \% \\
\text { of DM }\end{array}$} & \multicolumn{4}{|c|}{ Forage $^{1}$} \\
\hline & CCS & BMR & FAH & $\mathrm{HAH}$ \\
\hline DM, \% & $28.5 \pm 1.96$ & $27.5 \pm 1.30$ & $90.4 \pm 0.85$ & $93.8 \pm 0.86$ \\
\hline $\mathrm{OM}$ & $94.7 \pm 0.31$ & $93.3 \pm 0.42$ & $89.4 \pm 0.70$ & $89.1 \pm 0.32$ \\
\hline $\mathrm{CP}$ & $8.40 \pm 0.419$ & $8.30 \pm 0.369$ & $18.4 \pm 0.27$ & $20.7 \pm 1.49$ \\
\hline NDF & $44.8 \pm 2.45$ & $52.2 \pm 2.60$ & $46.7 \pm 3.04$ & $39.2 \pm 3.02$ \\
\hline IVNDFD, $^{2} \%$ & $62.2 \pm 2.96$ & $71.4 \pm 1.59$ & $37.9 \pm 4.43$ & $46.7 \pm 3.99$ \\
\hline $\mathrm{ADF}$ & $25.0 \pm 1.36$ & $28.4 \pm 1.38$ & $32.6 \pm 1.60$ & $28.5 \pm 3.09$ \\
\hline Ether extract & $2.71 \pm 0.132$ & $2.22 \pm 0.231$ & $1.63 \pm 0.112$ & $2.20 \pm 0.113$ \\
\hline $\mathrm{ADL}$ & $2.97 \pm 0.28$ & $2.94 \pm 0.13$ & $6.08 \pm 0.52$ & $5.02 \pm 1.0$ \\
\hline $\mathrm{NFC}^{3}$ & 38.8 & 30.6 & 22.7 & 27.0 \\
\hline
\end{tabular}


Table 2. Ingredients and chemical composition (means \pm SD) of the experimental diets fed to lactating cows $(\mathrm{n}=4$ sample replicates $)$

\begin{tabular}{|c|c|c|c|c|}
\hline \multirow[b]{3}{*}{ Item } & \multicolumn{4}{|c|}{ Experimental diet ${ }^{1}$} \\
\hline & \multicolumn{2}{|c|}{ CCS } & \multicolumn{2}{|c|}{ BMR } \\
\hline & FAH & HAH & FAH & HAH \\
\hline \multicolumn{5}{|l|}{ Ingredient, $\%$ of $\mathrm{DM}$} \\
\hline Conventional corn silage & 35.1 & 35.1 & - & - \\
\hline Brown midrib corn silage & — & - & 35.1 & 35.1 \\
\hline Alfalfa hay & 24.8 & 24.8 & 24.8 & 24.8 \\
\hline Corn grain, flaked & 18.4 & 18.4 & 18.4 & 18.4 \\
\hline Corn dried distillers grains with solubles & 7.80 & 7.80 & 7.80 & 7.80 \\
\hline Cottonseed, whole & 5.42 & 5.42 & 5.42 & 5.42 \\
\hline Soybean meal, $48 \%$ CP & 4.37 & 2.21 & 3.79 & 2.00 \\
\hline Beet pulp, pellets & 1.91 & 4.07 & 2.49 & 4.30 \\
\hline Calcium carbonate & 1.21 & 1.21 & 1.21 & 1.21 \\
\hline Salt & 0.31 & 0.31 & 0.31 & 0.31 \\
\hline Urea & 0.26 & 0.26 & 0.26 & 0.26 \\
\hline Magnesium oxide & 0.18 & 0.18 & 0.18 & 0.18 \\
\hline Sodium bicarbonate & 0.10 & 0.10 & 0.10 & 0.10 \\
\hline Vitamin and mineral mix $^{2}$ & 0.14 & 0.14 & 0.14 & 0.14 \\
\hline \multicolumn{5}{|l|}{ Chemical composition, \% of DM } \\
\hline DM, \% & $53.2 \pm 0.34$ & $53.1 \pm 3.00$ & $50.1 \pm 3.70$ & $50.3 \pm 1.68$ \\
\hline $\mathrm{OM}$ & $92.6 \pm 0.58$ & $92.2 \pm 0.62$ & $91.9 \pm 0.56$ & $91.7 \pm 0.35$ \\
\hline $\mathrm{CP}$ & $16.0 \pm 0.96$ & $16.0 \pm 0.41$ & $15.7 \pm 0.68$ & $15.7 \pm 0.69$ \\
\hline $\mathrm{RDP}^{3}$ & 10.2 & 10.3 & 10.0 & 10.2 \\
\hline RUP $^{3}$ & 5.80 & 5.70 & 5.70 & 5.50 \\
\hline $\mathrm{NDF}$ & $36.7 \pm 1.65$ & $35.7 \pm 2.53$ & $39.2 \pm 2.87$ & $38.3 \pm 1.84$ \\
\hline $\mathrm{ADF}$ & $20.6 \pm 0.86$ & $20.8 \pm 1.85$ & $22.6 \pm 2.41$ & $22.1 \pm 1.37$ \\
\hline Ether extract & $2.31 \pm 0.239$ & $1.82 \pm 0.279$ & $2.51 \pm 0.242$ & $2.01 \pm 0.256$ \\
\hline $\mathrm{NFC}^{4}$ & 37.6 & 38.7 & 34.5 & 35.7 \\
\hline $\mathrm{NE}_{\mathrm{L}},{ }^{3} \mathrm{Mcal} / \mathrm{kg}$ & 1.57 & 1.57 & 1.56 & 1.57 \\
\hline
\end{tabular}

${ }^{1}$ CCS-FAH $=$ conventional corn silage $(\mathrm{CCS})$ and fair-quality alfalfa hay $(\mathrm{FAH})$ diet; CCS-HAH $=$ CCS and high-quality alfalfa hay $(\mathrm{HAH})$ diet; $\mathrm{BMR}-\mathrm{FAH}=$ brown midrib corn silage (BMR) and FAH diet; and BMR$\mathrm{HAH}=\mathrm{BMR}$ and $\mathrm{HAH}$ diet.

${ }^{2}$ Formulated to contain (per $\mathrm{kg}$ of DM): $226.7 \mathrm{mg}$ of Se (from sodium selenite), 9,278.7 $\mathrm{mg}$ of $\mathrm{Cu}$ (from copper amino acid complex), 40,537.4 $\mathrm{mg}$ of $\mathrm{Zn}$ (from zinc amino acid complex), 38,653.4 $\mathrm{mg}$ of $\mathrm{Mn}$ (from manganese amino acid complex), $552.6 \mathrm{mg}$ of Co (from cobalt carbonate), 1,234,585.2 IU of vitamin A, 152,808.1 IU of vitamin D, 3,815.1 IU of vitamin E, and $295 \mathrm{mg}$ of Rumensin (Elanco Animal Health, Greenfield, IN).

${ }^{3}$ Based on tabular values (NRC, 2001).

${ }^{4} \mathrm{NFC}=100-\mathrm{CP}-\mathrm{NDF}-$ ether extract - ash

pany, St. Louis, MO) were planted during spring 2010 at the Utah State University South Farm (Wellsville). Corn silages were harvested at approximately $30 \%$ whole-plant DM, using a pull-type harvester (model FP230, New Holland USA, New Holland, PA) equipped with a mechanical processor, and treated with a silage inoculant (Silage PT, Nurturite, Twin Falls, ID) at a rate of $112 \mathrm{~g} / \mathrm{t}$ of fresh forage to enhance Lactobacillus fermentation. Silage hybrids were placed in bag silos (Ag/Bag International Ltd., Warrenton, OR) and ensiled for $120 \mathrm{~d}$. Alfalfa was preserved as sun-cured hay and processed for approximately $15 \mathrm{~min}$ in a TMR wagon (model 455, Roto-Mix, Dodge City, KS). Cows were housed in individual tiestalls fitted with rubber mattresses and bedded with straw and were fed a TMR for ad libitum intake with at least $10 \%$ of daily feed refusals. All cows were individually fed twice daily at 0830 and $1500 \mathrm{~h}$ with approximately $70 \%$ and $30 \%$ of total daily feed allocation at each feeding, respectively. Feed offered and refused was recorded daily, and daily samples were collected to determine DMI. Cows had free access to water.

Cows were milked twice daily at 0400 and $1600 \mathrm{~h}$. Milk production was recorded daily throughout the experiment. Cows were turned outside to a dry lot for exercise for at least $1 \mathrm{~h}$ daily in the morning after being milked. Milk was sampled during the a.m. and p.m. milkings on 3 consecutive days (d 16 to 18 ) in each period. Milk samples were preserved with Broad Spectrum Microtabs II (D\&F Control Systems Inc., San Ramon, $\mathrm{CA}$ ), and were stored at $4^{\circ} \mathrm{C}$. Individual milk samples were analyzed for fat, true protein, lactose, and MUN by the Rocky Mountain DHIA Laboratory (Wellsville, UT) with mid-infrared wave-band (2 to $15 \mu \mathrm{m}$ ) procedures using an infrared instrument (Bentley 2000, Bentley Instruments, Chaska, MN) calibrated weekly 
using raw milk standards provided by Eastern Laboratory Services (Fairlawn, OH). An enzymatic procedure was used to determine MUN using a Chemspec 150 instrument (Bentley Instruments). Milk composition was expressed on weighted milk yield of a.m. and p.m. samples. Milk fat and protein yields were calculated by multiplying milk yield from the respective day by fat and true protein concentrations of the milk on an individual cow. To convert milk total protein (TP) to milk $\mathrm{N}, 6.38$ was used as the conversion factor (DePeters and Cant, 1992), and total milk N (g/d) was calculated as milk TP/6.38 + MUN, where milk TP and MUN were expressed in grams per day.

\section{Feed Sampling and Analysis}

Corn silages and AH were sampled weekly to determine DM concentration and composited for each period. Diets were adjusted weekly to account for changes in DM concentration. Samples of the TMR fed and orts for individual cows were collected daily during the data collection period, dried at $60^{\circ} \mathrm{C}$ for $48 \mathrm{~h}$, ground to pass a 1-mm screen (standard model 4, Arthur H. Thomas Co., Swedesboro, NJ), and stored for subsequent analyses.

Analytical DM concentration of samples was determined by oven drying at $135^{\circ} \mathrm{C}$ for $3 \mathrm{~h}$ (AOAC International, 2000; method 930.15), and OM was determined by ashing at $550^{\circ} \mathrm{C}$ for $5 \mathrm{~h}$ (AOAC International, 2000; method 942.05). Concentration of $\mathrm{N}$ was determined using an elemental analyzer (Leco TruSpec N, St. Joseph, MI; AOAC International, 2000; method 990.03). The $\mathrm{NDF}$ and ADF concentrations were sequentially determined using an Ankom ${ }^{200 / 220}$ Fiber Analyzer (Ankom Technology, Macedon, NY) according to the methodology supplied by the company, which is based on the methods described by Van Soest et al. (1991). Sodium sulfite was used in the procedure for NDF determination and pretreatment with heat-stable amylase (type XI-A from Bacillus subtilis; Sigma-Aldrich Corp., St. Louis, MO). Ether extract was measured (AOAC International, 2000; method 2003.05) using an AnkomXT20 Fat Analyzer (Ankom Technology). In addition, ADL was determined as outlined in AOAC International (2000; method 973.18); the samples were soaked in 12 $M$ sulfuric acid for $3 \mathrm{~h}$ and thoroughly washed with boiling distilled water.

Feed DM and nutrient digestibility were measured during the last week in each period using acid-insoluble ash as an internal marker (Van Keulen and Young, 1977). Fecal samples (approximately $100 \mathrm{~g}$, wet weight) were collected for each cow from the rectum twice daily (a.m. and p.m.) every $12 \mathrm{~h}$, moving ahead $2 \mathrm{~h}$ each day for the $5 \mathrm{~d}$ sampling of feces beginning on $\mathrm{d} 15$.
This schedule provided 12 representative samples of feces for each cow. Samples were composited across sampling times for each cow, dried at $60^{\circ} \mathrm{C}$ for $72 \mathrm{~h}$, ground to pass a 1-mm screen (standard model 4, Arthur H. Thomas Co.), and stored for chemical analysis. Apparent total-tract DM and nutrient digestibilities were calculated from concentrations of acid-insoluble ash and nutrients in diets fed, orts, and feces.

\section{In Vitro NDF Degradation of CS and AH}

The Daisy II in vitro fermentation system (Ankom Technology) was used to examine the NDF degradation of $\mathrm{CS}$ and $\mathrm{AH}$ used in the lactation trial. Five hundred milligrams ( $\pm 20 \mathrm{mg}$ ) of $\mathrm{CS}$ or $\mathrm{AH}$ was weighed into artificial fiber bags (\#F57, Ankom Technology), which were then heat-sealed. Ruminal fluid was collected $4 \mathrm{~h}$ after the morning feeding $(1100 \mathrm{~h})$ from 2 ruminally cannulated, dry Holstein cows fed a diet containing $51.1 \%$ alfalfa hay, $23.4 \%$ wheat straw, $21.5 \%$ oat hay, $2.6 \%$ CCS, $1.0 \%$ wheat middlings, and $0.4 \%$ vitamin and trace mineral supplement. To prepare the ruminal fluid, ruminal contents were obtained from various locations within the rumen and composited. The ruminal contents were placed in sealed containers, transported to the laboratory, and strained through a polyester screen (pore size $355 \mu \mathrm{m}$; B \& S H Thompson, Ville Mont-Royal, QC, Canada) under a stream of oxygen-free $\mathrm{CO}_{2}$. Four hundred milliliters of ruminal fluid ( $\mathrm{pH}$ of 6.7 ) was then added to each fermentation jar together with 1,600 $\mathrm{mL}$ of anaerobic buffer, and fermentation was allowed to continue for $30 \mathrm{~h}$ at $39^{\circ} \mathrm{C}$. Bags were removed in quadruplicate (plus 1 empty bag) at $30 \mathrm{~h}$ of incubation, and then washed under cold tap water until excess water ran clear. Bags were dried at $55^{\circ} \mathrm{C}$ for $48 \mathrm{~h}$, and NDF degradation was determined using the same procedure described for feed analysis. The experiment was replicated on 2 occasions.

\section{Ruminal pH Measurement}

Ruminal $\mathrm{pH}$ was continuously measured for 2 consecutive days starting on d 18 using the Lethbridge Research Centre Ruminal pH Measurement System (LRCpH; Dascor, Escondido, CA) as described by Penner et al. (2006). Readings in $\mathrm{pH}$ buffers 4 and 7 were recorded before placing the $\mathrm{LRCpH}$ system in the rumen. Ruminal $\mathrm{pH}$ readings were taken every $30 \mathrm{~s}$ and stored by the data logger. After about $48 \mathrm{~h}$ of continuous $\mathrm{pH}$ measurement, the $\mathrm{LRCpH}$ was removed from the rumen and washed in $39^{\circ} \mathrm{C}$ water; then, millivolt readings were recorded in $\mathrm{pH}$ buffers 4 and 7 . The daily ruminal $\mathrm{pH}$ data was averaged for each minute and summarized as minimum $\mathrm{pH}$, mean $\mathrm{pH}$, and maximum 
$\mathrm{pH}$. In addition, number of daily episodes, duration $(\mathrm{h} / \mathrm{d})$, and area $(\mathrm{pH} \times \min )$ when ruminal $\mathrm{pH}$ was $<5.8$ were calculated. The threshold 5.8 was assigned because it has been defined by others (Nocek, 1997; Maekawa et al., 2002; Beauchemin and Yang, 2005) as the point below which ruminal acidosis occurs.

\section{Ruminal Fermentation Characteristics}

Ruminal contents were sampled 0,3 , and $6 \mathrm{~h}$ after the a.m. feeding on $\mathrm{d} 20$ and 21. Approximately $1 \mathrm{~L}$ of ruminal contents was obtained from the anterior dorsal, anterior ventral, medial ventral, posterior dorsal, and posterior ventral locations within the rumen, composited by cow, and strained through a polyester screen (pore size $355 \mu \mathrm{m}$ ). Five milliliters of the filtered ruminal fluid was added to $1 \mathrm{~mL}$ of $1 \%$ sulfuric acid and samples were retained for $\mathrm{NH}_{3}-\mathrm{N}$ determination. Concentration of $\mathrm{NH}_{3}-\mathrm{N}$ in the ruminal contents was determined as described by Rhine et al. (1998). Another $5 \mathrm{~mL}$ of the filtered ruminal fluid was taken 3 $\mathrm{h}$ after the a.m. feeding and added to $1 \mathrm{~mL}$ of $25 \%$ of meta-phosphoric acid, and the samples were retained for VFA determination. The VFA were quantified using a gas chromatograph (model 5890, Hewlett-Packard, Palo Alto, CA $)$ with a capillary column $(30 \mathrm{~m} \times 0.32$ $\mathrm{mm}$ i.d., 1- $\mu \mathrm{m}$ phase thickness, Zebron ZB-FAAP, Phenomenex, Torrance, CA) and flame-ionization detection. The oven temperature was $170^{\circ} \mathrm{C}$ held for $4 \mathrm{~min}$, which was then increased by $5^{\circ} \mathrm{C} / \mathrm{min}$ to $185^{\circ} \mathrm{C}$, and then by $3^{\circ} \mathrm{C} / \mathrm{min}$ to $220^{\circ} \mathrm{C}$, and held at this temperature for $1 \mathrm{~min}$. The injector temperature was $225^{\circ} \mathrm{C}$, the detector temperature was $250^{\circ} \mathrm{C}$, and the carrier gas was helium (Eun and Beauchemin, 2007).

\section{Urine Sampling and Analysis}

Spot urine samples were collected for each cow on d 18 to 21 at 0600 and 1800 h. Samples of urine were acidified to $\mathrm{pH}<4.0$ by using $4 \mathrm{M} \mathrm{HCl}$ and frozen $\left(-20^{\circ} \mathrm{C}\right)$, and this solution was later thawed and composited for each cow during each period and diluted with 39 parts diluent to 1 part urine. Diluent was $0.202 \%$ sodium 1-heptane sulfonic acid and $0.086 \%$ ammonium dihydrogen phosphate $\left(\mathrm{NH}_{4} \mathrm{H}_{2} \mathrm{PO}_{4}\right)$, and the solution was brought to $\mathrm{pH} 2.1$ with $4 \mathrm{M} \mathrm{HCl}$. The ratio of urinary purine derivatives (PD) to creatinine is widely used to estimate the microbial CP (MCP) flow to the duodenum (Gonda, 1995; Shingfield and Offer, 1998). Both PD and creatinine were analyzed by using an HPLC instrument (Waters Corp., Milford, MA) according to the procedures of Shingfield and Offer (1999). Urinary creatinine was used as a marker to estimate urine volume (Valadares et al., 1999; Leonardi et al., 2003). In calculating urine volume, we assumed that creatinine output averaged $28 \mathrm{mg} / \mathrm{kg}$ of BW, as estimated by Whittet (2004). Previous investigators have reported similar daily creatinine outputs, ranging from 25 to $30 \mathrm{mg} / \mathrm{kg}$ of BW (McCarthy et al., 1983; Jones et al., 1990). The ratio of the urinary PD allantoin and uric acid to creatinine was used to estimate the relative differences in MCP production (Shingfield and Offer, 1998). Based on estimates of urinary excretion of $\mathrm{PD}$, MCP supply was estimated according to the method of Chen and Gomes (1992).

\section{Statistical Analyses}

Data were summarized for each cow by measurement period. All data were statistically analyzed using the mixed model procedure in SAS (SAS Institute, 2012). Data for intake, digestibility, milk production, VFA profiles, $\mathrm{N}$ utilization, and urinary metabolites were analyzed with a model that included the effects of type of CS in the diet (CCS vs. BMR), type of AH (FAH vs. $\mathrm{HAH}$ ), and their interaction. Cow and period were the terms of the random statement.

Data for $\mathrm{NH}_{3}-\mathrm{N}$ concentration were analyzed using the model described above except that the fixed effect of time after feeding was included using the repeated option. The covariance structure that resulted in the lowest values for the Akaike information criterion and Schwarz's Bayesian criterion was used (Littell et al., 1998). Data for intakes of DM and nutrients and digestibilities were reported using the heterogeneous compound symmetry structure, whereas milk yield were analyzed by the autoregressive structure. Data for milk components and efficiency of feed and $\mathrm{N}$ utilization were analyzed using the unstructured covariance structure. In addition, data for VFA, $\mathrm{NH}_{3}-\mathrm{N}$, and excretion of urinary components (creatinine, allantoin, and uric acid) were analyzed by the unstructured variancecovariance structure.

Residual errors were used to test main effects and interactions. Differences were considered significant at $P<0.05$ and trends were discussed at $0.05<P<0.10$. When the interaction between type of $\mathrm{CS}$ and $\mathrm{AH}$ in the diet was $P<0.10$, Bonferroni-adjusted $P$-values were used to assess the effects of AH within type of CS. Results are reported as least squares means.

\section{RESULTS AND DISCUSSION}

\section{Characteristics of $\mathrm{CS}, \mathrm{AH}$, and Diets}

Chemical composition of forages fed during the experiment is outlined in Table 1. Mean concentrations of $\mathrm{DM}$ and $\mathrm{CP}$ were similar between CCS and BMR. On 
average, concentrations of NDF and ADF were slightly higher for BMR than for CCS, but both silages were higher in NDF than expected, which could have been because the growing season was shorter and colder than normal, forcing an immature harvest of both corn crops. It should be noted that the BMR had a lower concentration of NFC compared with the CCS (30.6 vs. $38.8 \%$ ), which may suggest that the BMR was even less mature than the CCS. As expected, in vitro NDF degradability measured after $30 \mathrm{~h}$ of in vitro incubation was higher for BMR compared with CCS (71.4 vs. $62.2 \%$ ). Chemical compositions of $\mathrm{AH}$ were similar to those of comparable quality reported by Mertens (2002), with concentrations higher for CP and lower for NDF in HAH compared with FAH (20.7 vs. $18.4 \%$ and 39.2 vs. $46.7 \%$, respectively). Additionally, in vitro NDF degradability for $\mathrm{AH}$ after $30 \mathrm{~h}$ of in vitro incubation was greater for HAH than for FAH (46.7 vs. $37.9 \%)$.

Ingredients and chemical composition of experimental diets are listed in Table 2. Concentration of CP in the CCS-based diets was as expected $(16.0 \%)$, but that in the BMR-based diets was slightly lower than expected (15.7\%), because the CP of BMR was lower than in the original analysis that was used for diet formulation. The concentration of estimated RDP averaged $10.1 \%$ DM across all diet treatments. Differences existed in NDF and NFC concentrations between CS hybrids, causing BMR-based diets to be slightly higher in NDF concentration and slightly lower for NFC concentration (38.4 vs. $35.6 \%$ and 35.1 vs. $38.2 \%$ for BMR- vs. CCS-based diet, respectively), whereas $\mathrm{NE}_{\mathrm{L}}$ was similar among all diets, perhaps due to higher ruminal degradability for the BMR.

\section{Intake, Digestibility, and Milk Production}

Intake of DM averaged $24.1 \mathrm{~kg} / \mathrm{d}$ across all diets and was not affected by dietary treatments (Table 3). Additionally, intakes of $\mathrm{OM}$ and $\mathrm{CP}$ were not influenced by source of CS and AH. Because of the higher concentration of NDF in BMR, however, cows fed BMR-based diets had slightly higher intakes of NDF compared with those fed CCS-based diets (10.2 vs. $9.17 \mathrm{~kg} / \mathrm{d})$. Quality of AH did not affect intake of fiber. No interaction effect between source of CS and AH was found for any measure of intake. We would not expect any effect on DMI in response to feeding different CS in our experiment because of the relatively short experimental periods and early stage of lactation. We recently reported that, through peak lactation (1-60 DIM), DMI was not different between CCS- and BMR-based diet, whereas DMI after peak lactation (61-180 DIM) tended to increase $(P=0.07)$ when feeding the BMR-based diet compared with the CCS-based diet (25.8 vs. $24.7 \mathrm{~kg} / \mathrm{d}$; Holt et al., 2013). Feeding diets with increased NDF digestibility such as BMR may allow for greater feed intake during mid-lactation when ruminal distension from gut fill becomes the dominant mechanism controlling intake, but the effect may be less apparent during early lactation when feed intake is controlled primarily by oxidation of metabolic fuels in the liver (Allen et al., 2009; Holt et al., 2013). In addition, Kung et al. (2008) speculated that experimental periods longer than $3 \mathrm{wk}$ may be needed for sufficient differences in intake to be expressed when cows are fed with BMR. Other studies have reported a lack of effects on DMI when feeding BMR in studies with 21-d periods (Weiss and Wyatt, 2006; Holt et al., 2010). Although HAH is very palatable and consequently can increase feed intake of cows, it failed to affect intake of DM and nutrients in this study.

Total-tract digestibilities of DM and OM did not differ in response to CS hybrids (Table 3), which agrees well with previous studies conducted with BMR (Taylor and Allen, 2005a; Weiss and Wyatt, 2006; Holt et al., 2010). In general, nutrient digestibilities with BMRbased diets are similar to or slightly higher than those of diets with CCS hybrids (Weiss and Wyatt, 2006). However, in one experiment, Gehman et al. (2008) reported DM digestibility to be reduced for BMR diets, likely because of the negatively associative effect between intake and digestibility. In the current study, total-tract digestibilities of DM and OM increased when feeding HAH compared with FAH. High-quality AH has a greater concentration of $\mathrm{CP}$ and $\mathrm{NFC}$ with less fiber than FAH, and NFC in alfalfa had been reported to be approximately $45 \%$ pectin (Martin and Mertens, 2005). Because pectin ferments rapidly and completely, it is likely that the $\mathrm{HAH}$ would have a higher digestibility of DM and OM compared with the FAH. Total-tract digestibility of CP was higher for CCS-based diets compared with BMR-based diets. The mechanism by which BMR-based diets decreased CP digestibility is difficult to explain. It is likely that greater passage of substrate from the rumen in cows fed BMR-based diets may have increased hindgut fermentation and decreased apparent total-tract CP digestibility when intake was increased (Tine et al., 2001; Gehman et al., 2008), but no differences in DMI were observed in the current study. Previous research done by our group showed that BMRbased diets fed with high concentrations of $\mathrm{AH}(25 \%$ DM) resulted in decreased CP digestibility with similar intakes (Holt et al., 2010). Total-tract digestibility of $\mathrm{CP}$ was not affected by quality of $\mathrm{AH}$. No differences were observed for NDF and ADF digestibilities due to dietary treatments. We observed no interaction between source of CS and $\mathrm{AH}$ on any measure of digestibility. 
Table 3. Nutrient intake and total-tract digestibility of lactating cows fed conventional (CCS) or brown midrib corn silage (BMR) with fairquality (FAH) or high-quality alfalfa hay ( $\mathrm{HAH})$

\begin{tabular}{|c|c|c|c|c|c|c|c|c|}
\hline Item & \multicolumn{4}{|c|}{ Diet } & SEM & & & \\
\hline \multicolumn{9}{|c|}{ Intake, $\mathrm{kg} / \mathrm{d}$} \\
\hline DM & 23.4 & 24.5 & 23.9 & 24.6 & 1.46 & 0.70 & 0.24 & 0.81 \\
\hline $\mathrm{OM}$ & 21.7 & 22.6 & 21.7 & 22.6 & 1.35 & 0.85 & 0.27 & 0.79 \\
\hline $\mathrm{ADF}$ & 5.77 & 5.29 & 6.12 & 6.04 & 0.371 & 0.01 & 0.19 & 0.33 \\
\hline \multicolumn{9}{|c|}{ Digestibility, \% } \\
\hline DM & 67.5 & 73.6 & 67.3 & 70.4 & 1.92 & 0.29 & $<0.01$ & 0.34 \\
\hline $\mathrm{OM}$ & 70.1 & 75.6 & 70.0 & 72.6 & 1.78 & 0.30 & 0.01 & 0.34 \\
\hline CP & 70.1 & 72.4 & 67.4 & 68.6 & 1.97 & 0.05 & 0.28 & 0.75 \\
\hline NDF & 55.8 & 58.5 & 55.9 & 56.6 & 2.58 & 0.61 & 0.36 & 0.59 \\
\hline $\mathrm{ADF}$ & 53.4 & 56.9 & 54.5 & 55.7 & 2.99 & 0.97 & 0.29 & 0.59 \\
\hline
\end{tabular}

${ }^{1} \mathrm{CS}=$ type of corn silage in the diet (CCS vs. BMR), AH = type of alfalfa hay in the diet (FAH vs. HAH), and CS $\times$ AH $=$ interaction between $\mathrm{CS}$ and $\mathrm{AH}$.

Although the proportion of potentially digestible NDF was greater for BMR, the lack of response in total-tract NDF digestibility has been observed by others (Oba and Allen, 2000; Gehman et al., 2008) and is believed to occur when intake is increased (Oba and Allen, 2000). Grasses often have greater proportion of potentially digestible NDF and higher in vitro NDF digestibility than legume forages, but rate of digestion of legume NDF is faster (Smith et al., 1972) and could increase total amount of NDF digested. The effect of feeding high concentrations of western AH in BMR-based diets may increase the passage rate, diluting potential effects of BMR in ruminal digestion (Holt et al., 2010).

Milk production and efficiencies are presented in Table 4 . On average, milk and 3.5\% FCM yields were observed to be 40.7 and $40.4 \mathrm{~kg} / \mathrm{d}$, respectively, and were not influenced by CS hybrid or quality of $\mathrm{AH}$. Similarly, concentrations of milk fat, true protein, and lactose, and yields of these major milk components were not observed to be different among treatments. In a review of 11 published studies, it was noted that cows fed BMR were generally more productive than those fed CCS; milk yield was $1.7 \mathrm{~kg} / \mathrm{d}$ greater with a $1.2 \mathrm{~kg} / \mathrm{d}$ increase in DMI for cows fed BMR, and yield of milk fat was greater for BMR compared with CCS $(1.40$ vs. $1.36 \mathrm{~kg} / \mathrm{d})$, but milk fat concentration tended to be reduced $(P=0.10)$ by 0.08 percentage units and was related to greater milk yield for these cows (Gencoglu et al., 2008). The increased milk yield by cows fed BMR is generally attributed to an increase in DMI. As seen in our study, with no effect on DMI, no difference in milk yield is in agreement with our recent finding that milk yield was not different between CCS- and
BMR-based diets through peak lactation (Holt et al., 2013), but milk yield after peak lactation increased by feeding the BMR-based diet compared with the CCSbased diet (41.0 vs. $38.8 \mathrm{~kg} / \mathrm{d}$ ).

\section{Utilization of $N$}

Nitrogen intake and secretion into milk averaged 623 and $193 \mathrm{~g} / \mathrm{d}$, respectively, with no differences observed among treatments (Table 5). However, BMR-based diets tended to increase $(P=0.08)$ efficiency of feed $\mathrm{N}$ to milk $\mathrm{N}$ compared with CCS-based diets (0.33 vs. 0.31 ), primarily because the BMR-based diets secreted numerically more $\mathrm{N}$ into milk with less intake of feed N. Concentration of MUN decreased by feeding BMRbased diets. Others have reported decreased MUN concentrations when feeding BMR (Taylor and Allen, 2005b; Kung et al., 2008; Holt et al., 2010). A lower MUN concentration with similar milk protein yield suggests that cows fed BMR may have been more efficient in converting feed $\mathrm{N}$ into milk and body tissue $\mathrm{N}$. Jonker et al. (1998) indicated that MUN is indirectly affected by efficiency of ruminal $\mathrm{N}$ fermentation and carbohydrate digestibility, through an increase in milk $\mathrm{N}$ secretion, a decrease in $\mathrm{N}$ intake, or an increase in fecal N. In our study, feeding HAH further reduced MUN concentration, which may have been affected indirectly by increasing fecal N output. Furthermore, Jonker et al. (1998) stated that the amount of urea secreted into milk is proportional to the concentration of urea in blood, and this amount is directly proportional to the concentration of urea excreted into the urine of dairy cows. In the current study, concentrations of MUN, 
Table 4. Milk production and composition and efficiencies of DM and N use for milk production of lactating cows fed conventional (CCS) or brown midrib corn silage (BMR) with fair-quality (FAH) or high-quality alfalfa hay (HAH)

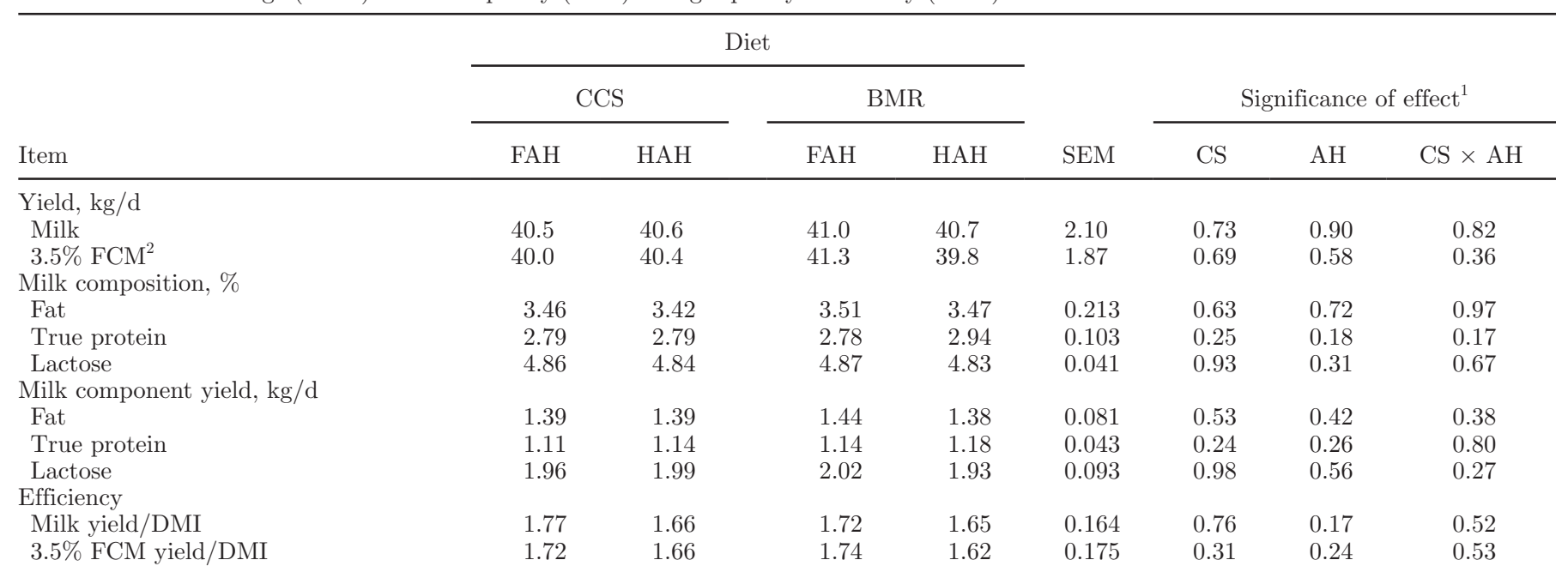

${ }^{1} \mathrm{CS}=$ type of corn silage in the diet (CCS vs. BMR), $\mathrm{AH}=$ type of alfalfa hay in the diet (FAH vs. HAH), and CS $\times \mathrm{AH}=$ interaction between $\mathrm{CS}$ and $\mathrm{AH}$.

${ }^{2} 3.5 \% \mathrm{FCM}=(0.4324 \times$ milk yield, $\mathrm{kg} / \mathrm{d})+(16.216 \times$ milk fat yield, $\mathrm{kg} / \mathrm{d})$.

BUN, and urinary urea $\mathrm{N}$ all followed the same pattern (being reduced by feeding BMR), and these concentrations were further reduced by feeding HAH.

Ruminal $\mathrm{NH}_{3}-\mathrm{N}$ concentration was lower for cows fed BMR-based diets than for those fed CCS based-diets (Table 5) but was not affected by quality of AH. This is consistent with the pattern observed for BUN and urinary urea $\mathrm{N}$ in the BMR-based diets. In the rumen, dietary protein is degraded to $\mathrm{NH}_{3}-\mathrm{N}$, absorbed into the blood, converted to urea in the liver, and excreted in the urine, resulting in a high correlation between these variables. Oba and Allen (2000) reported that ruminal

Table 5. Nitrogen utilization of lactating cows fed conventional (CCS) or brown midrib corn silage (BMR) with fair-quality (FAH) or highquality alfalfa hay $(\mathrm{HAH})$

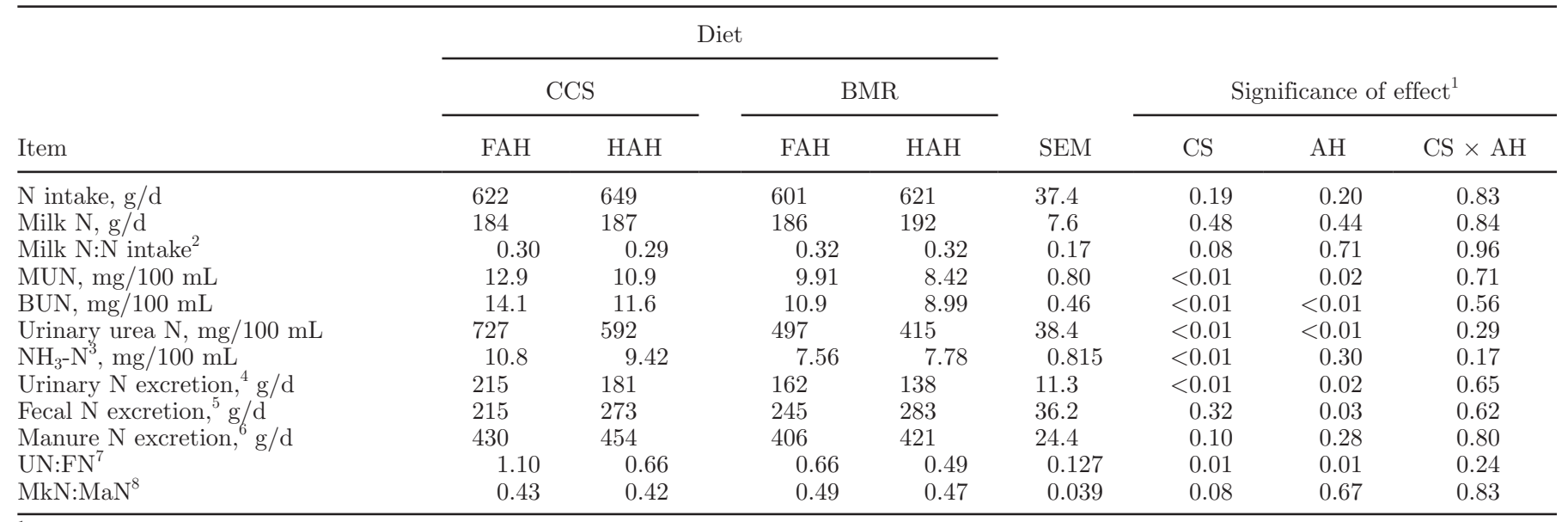

${ }^{1} \mathrm{CS}=$ type of corn silage in the diet (CCS vs. BMR), $\mathrm{AH}=$ type of alfalfa hay in the diet (FAH vs. HAH), and CS $\times \mathrm{AH}=$ interaction between $\mathrm{CS}$ and $\mathrm{AH}$.

${ }^{2}$ Efficiency of use of feed $\mathrm{N}$ to milk $\mathrm{N}$.

${ }^{3}$ Ruminal ammonia-N.

${ }^{4}$ Predicted using the following equation: $0.026 \times \mathrm{MUN}, \mathrm{mg} / 100 \mathrm{~mL} \times \mathrm{BW}, \mathrm{kg}$ (Wattiaux and Karg, 2004).

${ }^{5}$ Predicted using the following equation: $\mathrm{N}$ intake, $\mathrm{g} / \mathrm{d}-$ urinary $\mathrm{N}$ excretion, $\mathrm{g} / \mathrm{d}-$ milk $\mathrm{N}, \mathrm{g} / \mathrm{d}$.

${ }^{6}$ Manure $\mathrm{N}, \mathrm{g} / \mathrm{d}=$ urinary $\mathrm{N}$ excretion, $\mathrm{g} / \mathrm{d}+$ fecal $\mathrm{N}$ excretion, $\mathrm{g} / \mathrm{d}$.

${ }^{7} \mathrm{UN}: \mathrm{FN}=$ ratio of urinary $\mathrm{N}$ to fecal $\mathrm{N}$, where urinary $\mathrm{N}$ and fecal $\mathrm{N}$ are expressed in $\mathrm{g} / \mathrm{d}$.

${ }^{8} \mathrm{MkN}: \mathrm{MaN}=$ ratio of milk $\mathrm{N}$ to manure $\mathrm{N}$, where milk $\mathrm{N}$ and manure $\mathrm{N}$ are expressed in $\mathrm{g} / \mathrm{d}$. 
$\mathrm{NH}_{3}-\mathrm{N}$ concentration was reduced when BMR was fed, which they attributed to increased MCP synthesis. Others have reported a similar reduction in ruminal $\mathrm{NH}_{3}-\mathrm{N}$ concentration when feeding BMR (Weiss and Wyatt, 2006; Gehman et al., 2008; Holt et al., 2010), implying better ruminal N utilization when BMR is fed. Gehman et al. (2008) stated that the result is likely due to greater fiber digestion in the rumen, and cellulolytic bacteria such as Ruminococcus albus, Ruminococcus flavefaciens, and Fibrobacter succinogenes require $\mathrm{NH}_{3}-\mathrm{N}$ as an $\mathrm{N}$ source for growth (Russell et al., 1992). Furthermore, Ramirez Ramirez et al. (2012) reported that when cows were fed BMR compared with CCS, the population of Fibrobacter spp. tended $(P=0.15)$ to represent a larger proportion of the total bacterial population, and this shift may have been driven by the fact the BMR has less lignin. Consequently, the cellulose fermenters have more access to the cellulose in the diet.

Most studies have shown that the amount of $\mathrm{NH}_{3}$ produced from cattle manure in the short term (i.e., days) is strongly correlated with the amount of urinary $\mathrm{N}$ in the manure, which is strongly correlated with $\mathrm{N}$ intake (James et al., 1999; Cole et al., 2005). In the current study, feeding BMR-based diets with similar $\mathrm{N}$ intake reduced urinary $\mathrm{N}$ excretion by $25 \%$ with a tendency $(P=0.10)$ for less $\mathrm{N}$ excreted into manure (Table 5$)$. In contrast, fecal $\mathrm{N}$ excretions did not differ with source of CS. Cows fed HAH in their diets excreted $15 \%$ less N into urine, but they excreted more fecal $\mathrm{N}$, resulting in no effect on manure $\mathrm{N}$ excretion in response to feeding different quality of AH. From an extensive review of published studies, Castillo et al. (2000) reported that, on average, $72 \%$ of the $\mathrm{N}$ consumed by dairy cows was excreted into manure and that a linear relationship $\left(\mathrm{R}^{2}\right.$ $=0.93$ ) existed between $\mathrm{N}$ intake and $\mathrm{N}$ excretion into manure. Moreover, for $\mathrm{N}$ intake $>400 \mathrm{~g} / \mathrm{d}$, the proportion of $\mathrm{N}$ excreted into urine increased exponentially, whereas proportional $\mathrm{N}$ output into feces and milk declined linearly. Castillo et al. (2001) suggested that a reduction in dietary CP from 19.0 to $15.0 \%$ of diet DM would reduce urinary N excretion from 225 to 151 $\mathrm{g} / \mathrm{d}$ without significantly altering milk production. In our study, approximately $69 \%$ of the $\mathrm{N}$ consumed was excreted into the manure, with $\mathrm{N}$ intake and urinary $\mathrm{N}$ excretion averaging 623 and $174 \mathrm{~g} / \mathrm{d}$, respectively. Greenfield et al. (2001) and Tine et al. (2001) reported a reduction in urinary $\mathrm{N}$ excretion when feeding $\mathrm{BMR}$. Weiss and Wyatt (2006) reported that cows fed BMR with similar $\mathrm{N}$ intake tended to excrete $(P=0.08)$ less $\mathrm{N}$ via manure and secreted more $\mathrm{N}$ into milk. In an experiment by Gehman et al. (2008), BMR-based diets had greater $\mathrm{N}$ intake and greater fecal $\mathrm{N}$ excretion with no significant difference in milk $\mathrm{N}$, urinary $\mathrm{N}$, and manure $\mathrm{N}$ excretion. They suggested that the increase in fecal $\mathrm{N}$ excretion for the BMR-based diets was due to increased $\mathrm{N}$ intake and decreased $\mathrm{N}$ digestibility (Gehman et al., 2008).

Urinary $\mathrm{N}$ excretion-to-fecal $\mathrm{N}$ excretion ratio (UN:FN) and milk N-to-manure $\mathrm{N}$ ratio ( $\mathbf{M k N}: \mathbf{M a N})$ are reported in Table 5 . When less $\mathrm{N}$ is found in the urine relative to feces (lower UN:FN), less ammonia loss from manure is expected, because urinary $\mathrm{N}$ is more vulnerable to environmental loss than is fecal $\mathrm{N}$ (Wattiaux and Karg, 2004). Similarly, a higher MkN:MaN is more desirable, because it indicates that less manure $\mathrm{N}$ must be managed per unit of milk $\mathrm{N}$ produced by the herd. In our study, feeding BMR-based diets decreased the UN:FN and it was further reduced by feeding $\mathrm{HAH}$. Although cows fed the BMR-based diets tended to increase MkN:MaN $(P=0.08)$, quality of AH did not affect the ratio. The lower ratio of UN:FN with a greater ratio of MkN:MaN for the BMR-based diets indicates that feeding BMR may reduce manure $\mathrm{NH}_{3}-\mathrm{N}$ by reducing excretion of urinary $\mathrm{N}$ and increasing secretion of milk $\mathrm{N}$ per unit of manure $\mathrm{N}$ excreted. Feeding $\mathrm{HAH}$ shifted the route of $\mathrm{N}$ excretion from urine to feces, which is an effective way of reducing $\mathrm{NH}_{3}$ volatilization and resultant pollution. However, this benefit was not achieved on excretion of manure $\mathrm{N}$ by feeding the HAH. The faster passage rate for HAH may have increased fermentation in the hindgut, reducing microbial capture of RDP in the rumen and consequently causing an increase in fecal $\mathrm{N}$ excretion.

Contrary to our hypothesis, feeding HAH reduced urinary $\mathrm{N}$ excretion compared with FAH. However, cows fed BMR-FAH had the same UN:FN (0.66) as those fed CCS-HAH, and feeding BMR with FAH or $\mathrm{HAH}$ resulted in better MkN:MaN than feeding CCSbased diets, which supports our hypothesis that feeding BMR with FAH would maintain milk production in early lactation cows while improving $\mathrm{N}$ efficiency. It is assumed that quality of legume hay such as $\mathrm{AH}$ would affect the metabolic route of $\mathrm{N}$ excretion (Weiss et al., 2009); thus, we expect that feeding HAH would reduce the UN:FN compared with feeding $\mathrm{FAH}$, even in BMR-based diets. Similar concentrations of ruminal $\mathrm{NH}_{3}-\mathrm{N}$ between $\mathrm{FAH}$ and $\mathrm{HAH}$ in BMR diets (7.56 vs. $7.78 \mathrm{mg} / 100 \mathrm{~mL}$ ) may have contributed to the similar UN:FN. As the UN:FN did not differ sizably between FAH and HAH under BMR diets (0.66 vs. $0.49 ; P=$ 0.25 ), the nutritive quality of $\mathrm{AH}$ would not affect $\mathrm{N}$ utilization in view of environmental performance of dairy cows fed BMR due to enhanced nutrient utilization and its contribution to the overall $\mathrm{N}$ utilization by BMR. However, relatively small nutritive differences between FAH and HAH tested in our study should not be discounted on the extrapolation of our result on $\mathrm{UN}: \mathrm{FN}$. 


\section{Ruminal Fermentation Characteristics}

Cows fed CCS- or BMR-based diets maintained similar ruminal $\mathrm{pH}$ and its diurnal patterns (Table 6). A negative association of BMR and rumen $\mathrm{pH}$ has been observed in some studies (Greenfield et al., 2001; Gehman et al., 2008; Ramirez Ramirez et al., 2012). However, previous research in our laboratory, in which high dietary concentrations of AH (25\% DM) were fed with BMR silage, indicated similar mean ruminal $\mathrm{pH}$ (approximately 6.3) between CCS- and BMR-based diets (Holt et al., 2010, 2013). Feeding HAH increased maximum ruminal $\mathrm{pH}$ and duration below $\mathrm{pH} 5.8$ (h/d), but minimum and mean $\mathrm{pH}$ and daily episodes below $\mathrm{pH} 5.8$ were not affected by any dietary treatment. $\mathrm{Ru}-$ minal $\mathrm{pH}$ decreases only when hydrogen ion production exceeds removal from the rumen and ruminal buffering capacity (Taylor and Allen, 2005c). Substantially greater rate and extent of ruminal degradation by $\mathrm{HAH}$ compared with FAH likely resulted in a greater rate of VFA production with inadequate hydrogen ion removal and buffering to offset VFA production, resulting in a longer duration of time for ruminal $\mathrm{pH}<5.8$.

Total VFA concentration did not differ with source of CS, but cows fed HAH had a higher VFA concentration compared with those fed with FAH (Table 6). Beauchemin (1991) fed 2 different types of $\mathrm{AH}$ that were similar in NDF concentration to the AH used in the current study. That author reported higher VFA concentration for diets with HAH compared with FAH (Beauchemin, 1991). Additionally, the proportion of acetate increased, but that of propionate decreased as maturity advanced for AH (Beauchemin, 1991). Source of CS did not influence the molar proportion of acetate, but feeding $\mathrm{HAH}$ tended to decrease acetate $(P$ $=0.08)$. The molar proportion of propionate was not affected by source of CS, whereas it increased when $\mathrm{HAH}$ was fed only in CCS-based diet, resulting in a CS $\times \mathrm{AH}$ interaction. Cows fed CCS-based diets tended to increase $(P=0.10)$ butyrate proportion. Although ratios of acetate to propionate and acetate plus butyrate to propionate were similar between CCS-based and BMR-based diets, these ratios decreased when cows were fed with HAH only in CCS-based diets, leading to interactions between source of CS and AH. Feeding CCS-based diets increased the molar proportion of isobutyrate, whereas cows fed with HAH decreased molar proportion of isovalerate only in CCS-based diet, resulting in a $\mathrm{CS} \times \mathrm{AH}$ interaction. The effect of feeding BMR on total VFA concentration and molar proportions of individual VFA has not been consistent in the literature (Castro et al., 2010). Differences among experiments likely arise from interactions with other diet ingredients or cow effects. In our previous research with BMR fed with high dietary concentrations of $\mathrm{AH}$, we reported no differences in VFA concentration and molar proportions of individual VFA (Holt et al., 2010, 2013).

Table 6. Ruminal fermentation characteristics of lactating cows fed conventional (CCS) or brown midrib corn silage (BMR) with fair-quality $(\mathrm{FAH})$ or high-quality alfalfa hay $(\mathrm{HAH})$

\begin{tabular}{|c|c|c|c|c|c|c|c|c|}
\hline \multirow{2}{*}{ Item } & \multicolumn{4}{|c|}{ Diet } & \multirow{2}{*}{ SEM } & & & \\
\hline & \multicolumn{2}{|c|}{ CCS } & \multicolumn{2}{|c|}{ BMR } & & \multicolumn{3}{|c|}{ Significance of effect ${ }^{1}$} \\
\hline Minimum pH & 5.74 & 5.73 & 5.73 & 5.67 & 0.093 & 0.54 & 0.63 & 0.65 \\
\hline Mean pH & 6.43 & 6.50 & 6.47 & 6.43 & 0.058 & 0.76 & 0.63 & 0.20 \\
\hline \multicolumn{8}{|l|}{$\mathrm{pH}<5.8$} & 0.24 \\
\hline Duration, h/d & 0.22 & 3.19 & 0.33 & 1.94 & 1.539 & 0.61 & 0.05 & 0.55 \\
\hline Area, $\mathrm{pH} \times \min$ & 1.66 & 0.92 & 0.92 & 1.61 & 1.016 & 0.97 & 0.98 & 0.43 \\
\hline Total VFA, mM & 121 & 129 & 125 & 131 & 2.7 & 0.26 & 0.03 & 0.64 \\
\hline \multicolumn{9}{|c|}{ Individual VFA, mol/100 mol } \\
\hline Acetate (A) & 61.7 & 59.1 & 61.4 & 61.1 & 1.24 & 0.30 & 0.08 & 0.18 \\
\hline Propionate (P) & $21.2^{\mathrm{b}}$ & $24.8^{\mathrm{a}}$ & 22.8 & 23.1 & 0.80 & 0.72 & $<0.01$ & $<0.01$ \\
\hline Butyrate (B) & 12.6 & 11.6 & 11.2 & 11.1 & 0.55 & 0.10 & 0.35 & 0.36 \\
\hline
\end{tabular}

${ }^{\mathrm{a}, \mathrm{b}}$ Means in the same row within CCS and BMR subgroups with different superscripts differ based on Bonferroni-adjusted $P$-values $(P<0.05)$. ${ }^{1} \mathrm{CS}=$ type of corn silage in the diet (CCS vs. BMR), AH = type of alfalfa hay in the diet (FAH vs. HAH), and CS $\times$ AH $=$ interaction between $\mathrm{CS}$ and $\mathrm{AH}$. 


\section{$P D$ and Creatinine Excretion}

Effects of dietary treatments on urinary creatinine, $\mathrm{PD}$, ratio of $\mathrm{PD}$ to creatinine, ratio of allantoin to creatinine, and estimated MCP production by PD production according to Chen and Gomes (1992) are reported in Table 7. None of the measures differed across dietary treatments, except that creatinine production tended to decrease $(P=0.07)$ when cows were fed BMRbased diets compared with CCS-based diets. Although feeding BMR-based diets decreased ruminal $\mathrm{NH}_{3}-\mathrm{N}$ concentration, it did not contribute to MCP production. The ultimate goal of proper nutrient utilization in the rumen is to maximize microbial growth and the amount of RDP that is captured in rumen microbial cells. Maximizing the capture of degradable N not only improves the supply of AA to the small intestine, but also decreases N losses. Oba and Allen (2000) observed that feeding diets containing BMR increased microbial $\mathrm{N}$ flow to the duodenum as well as microbial efficiency, possibly because of a faster rate of passage. Their diets for BMR treatments differed from the CCS treatments by containing a greater inclusion of CS and less ground corn than the CCS treatments; however, diet composition was similar for NDF and starch concentrations (Oba and Allen, 2000). In contrast, Gehman et al. (2008) did not observe any difference in PD production or MCP flow with experimental diets that contained more CS and less ground corn in BMR treatments compared with CCS treatments. In the current experi- ment, CS and flaked corn were fed at the same dietary concentrations for both BMR and CCS treatments. However, diet compositions for BMR-based diets were slightly higher in NDF and approximately 3\% lower in NFC concentration compared with CCS-based diets. Given the fact that energy is the most limiting factor in microbial growth (Bach et al., 2005), it is interesting to note that the BMR treatments with relatively low NFC in the diets were able to maintain similar MCP production compared with CCS-based diets. Further research is required to understand the effects of BMR and quality of $\mathrm{AH}$ on rumen microbial community structure, MCP production, and their effects on milk yield and $\mathrm{N}$ utilization.

\section{CONCLUSIONS}

Dairy cows excrete substantially more $\mathrm{N}$ into manure than they secrete into milk, which increases milk production costs and environmental N pollution. Optimal dairy feeding programs should consider their effects on crop selection to maximize dairy production while reducing environmental effects. Decreased UN:FN because of feeding BMR or quality of $\mathrm{AH}$ highlights a great opportunity to improve efficiency of $\mathrm{N}$ utilization for dairy production by selecting forage crops that use $\mathrm{N}$ more efficiently. Feeding BMR increased MkN:MaN by channeling more dietary $\mathrm{N}$ into milk than to manure $\mathrm{N}$ excretion. Although $\mathrm{HAH}$ reduced $\mathrm{N}$ excretion into the urine, it only shifted the route from urine to fecal

Table 7. Daily excretion of urinary creatinine, allantoin, uric acid, and estimated ruminal microbial protein production of lactating cows fed conventional (CCS) or brown midrib corn silage (BMR) with fair-quality (FAH) or high-quality alfalfa hay (HAH)

\begin{tabular}{|c|c|c|c|c|c|c|c|c|}
\hline \multirow[b]{2}{*}{ Item } & \multicolumn{4}{|c|}{ Diet } & \multirow[b]{2}{*}{ SEM } & & & \\
\hline & FAH & $\mathrm{HAH}$ & FAH & НАH & & CS & $\mathrm{AH}$ & $\mathrm{CS} \times \mathrm{AH}$ \\
\hline Creatinine, $\mathrm{m} M$ & 8.62 & 9.02 & 8.92 & 8.86 & 0.382 & 0.81 & 0.58 & 0.45 \\
\hline Allantoin, $\mathrm{m} M$ & 11.0 & 10.4 & 10.8 & 9.61 & 1.08 & 0.65 & 0.36 & 0.76 \\
\hline Uric acid, $\mathrm{m} M$ & 1.51 & 1.54 & 1.59 & 1.65 & 0.035 & 0.01 & 0.27 & 0.67 \\
\hline Allantoin:creatinine & 1.29 & 1.18 & 1.23 & 1.09 & 0.141 & 0.49 & 0.28 & 0.90 \\
\hline Creatinine production ${ }^{3}$ & 160 & 158 & 156 & 158 & 5.1 & 0.07 & 0.92 & 0.14 \\
\hline PD production ${ }^{4}$ & 233 & 212 & 220 & 202 & 21.4 & 0.54 & 0.28 & 0.94 \\
\hline Allantoin production ${ }^{5}$ & 204 & 184 & 192 & 172 & 20.7 & 0.48 & 0.26 & 0.99 \\
\hline $\mathrm{MCP}_{,}^{6} \mathrm{~g} / \mathrm{d}$ & 1053 & 958 & 997 & 914 & - & - & - & - \\
\hline
\end{tabular}

${ }^{1} \mathrm{CS}=$ type of corn silage in the diet (CCS vs. BMR), $\mathrm{AH}=$ type of alfalfa hay in the diet (FAH vs. HAH), and CS $\times \mathrm{AH}=$ interaction between $\mathrm{CS}$ and $\mathrm{AH}$.

${ }^{2} \mathrm{PD}=$ total purine derivatives (allantoin + uric acid).

${ }^{3}$ Creatinine production, $\mathrm{mmol} / \mathrm{d}=(28 \times \mathrm{BW}) / 113.1$ (Janicek et al., 2008).

${ }^{4} \mathrm{PD}$ production, $\mathrm{mmol} / \mathrm{d}=[$ creatinine production $\times(\mathrm{PD}:$ creatinine $)]$.

${ }^{5}$ Allantoin production, $\mathrm{mmol} / \mathrm{d}=[$ creatinine production $\times$ (allantoin:creatinine $\left.)\right]$.

${ }^{6}$ Microbial protein production, $\mathrm{g} / \mathrm{d}=\left(\left\{\left[\mathrm{PD}\right.\right.\right.$ production $\left.\left.\left.-\left(0.385 \times \mathrm{BW}^{0.075}\right)\right] / 0.85\right\} \times 70 \times 6.25\right) /(0.13 \times 0.83 \times 1,000)(\mathrm{Janicek}$ et al., 2008$)$. A statistical test of the effects of treatment diets on ruminal microbial CP synthesis was not conducted, because microbial CP was calculated based on excretion of PD (Firkins et al., 2006). 
excretion without increasing the ratio of $\mathrm{MkN}: \mathrm{MaN}$. Overall $\mathrm{N}$ utilization data in the current study indicated that feeding forages higher in ruminal degradability such as BMR and HAH resulted in better $\mathrm{N}$ utilization, as evidenced by decreased concentrations of BUN, MUN, and urinary urea N, which can represent an environmental advantage over traditional sources of forages in lactation dairy diets. Because of stage of lactation and the experimental design, however, DMI and milk production were mostly unaffected by diet treatments tested in this study. Improving productive performance of dairy cows is a primary means to optimize dietary $\mathrm{N}$ utilization so as to proportionally reduce $\mathrm{N}$ emissions to environment; therefore, more animal experiments are needed to investigate the possibility that feeding BMR-based diets can take advantage of decreased $\mathrm{N}$ excretion to improve the productive performance of dairy cows.

\section{ACKNOWLEDGMENTS}

This study was supported by funds from Mycogen Seeds (Indianapolis, IN) and Utah State University Agricultural Experiment Station (Logan). The authors thank C. Dschaak and W. Burningham at Utah State University for technical assistance and the staff of the Caine Dairy Center (Wellsville, UT) for their conscientious care of the experimental cows.

\section{REFERENCES}

Allen, M. S., B. J. Bradford, and M. Oba. 2009. Board-Invited Review: The hepatic oxidation theory of the control of feed intake and its application to ruminants. J. Anim. Sci. 87:3317-3334.

AOAC International. 2000. Official Methods of Analysis. Vols. 1 and 2. 17th ed. AOAC Int., Gaithersburg, MD.

Bach, A., S. Calsamiglia, and M. D. Stern. 2005. Nitrogen metabolism in the rumen. J. Dairy Sci. 88(E. Suppl.):E9-E21.

Beauchemin, K. A. 1991. Effects of dietary neutral detergent fiber concentration and alfalfa hay quality on chewing, rumen function, and milk production of dairy cows. J. Dairy Sci. 74:3140-3151.

Beauchemin, K. A., and W. Z. Yang. 2005. Effects of physically effective fiber on intake, chewing activity, and ruminal acidosis for dairy cows fed diets based on corn silage. J. Dairy Sci. 88:2117-2129.

Castillo, A. R., E. Kebreab, D. E. Beever, J. H. Barbi, J. D. Sutton, H. C. Kirby, and J. France. 2001. The effect of protein supplementation on nitrogen utilization in lactating dairy cows fed grass silage diets. J. Anim. Sci. 79:247-253.

Castillo, A. R., E. Kebreab, D. E. Beever, and J. France. 2000. A review of efficiency of nitrogen utilization in lactating dairy cows and its relationship with environmental pollution. J. Anim. Feed Sci. 9:1-32.

Castro, J. J., J. K. Bernard, N. A. Mullis, and R. B. Eggleston. 2010. Brown midrib corn silage and Tifton 85 bermudagrass in rations for early-lactation cows. J. Dairy Sci. 93:2143-2152.

Chen, X. B., and M. J. Gomes. 1992. Estimation of microbial protein supply to sheep and cattle based on urinary excretion of purine derivatives - An overview of the technical details. Int. Feed. Res. Unit, Occas. Publ. Rowett Res. Inst., Bucksburn, Aberdeen, UK.

Cole, N. A., R. N. Clark, R. W. Todd, C. R. Richardson, A. Gueye, L. W. Greene, and K. McBride. 2005. Influence of dietary crude protein concentration and source on potential ammonia emissions from beef cattle manure. J. Anim. Sci. 83:722-731.

DePeters, E. J., and J. P. Cant. 1992. Nutritional factors influencing the nitrogen composition of bovine milk: A review. J. Dairy Sci. 75:2043-2070.

Eun, J.-S., and K. A. Beauchemin. 2007. Enhancing in vitro degradation of alfalfa hay and corn silage using feed enzymes. J. Dairy Sci. 90:2839-2851.

Firkins, J. L., A. N. Hristov, M. B. Hall, G. A. Varga, and N. R. StPierre. 2006. Integration of ruminal metabolism in dairy cattle. J. Dairy Sci. 89:E31-E51.

Gehman, A. M., P. J. Kononoff, C. R. Mullins, and B. N. Janicek. 2008. Evaluation of nitrogen utilization and the effects of monensin in dairy cows fed brown midrib corn silage. J. Dairy Sci. 91:288-300.

Gencoglu, H., R. Shaver, and J. Lauer. 2008. Brown midrib corn silage for lactating dairy cows: A contemporary review. Accessed Jan. 20, 2013. http://www.uwex.edu/ces/dairynutrition/documents/ BMRfeedingtrialreview2008web.pdf.

Gonda, H. L. 1995. Nutritional status of ruminants determined from excretion and concentration of metabolites in body fluids. $\mathrm{PhD}$ Diss. Swedish Univ. Agric. Sci., Dept. Anim. Nutr. Management, Uppsala, Sweden.

Greenfield, T. L., R. L. Baldwin, R. A. Erdman, and K. R. McLeod. 2001. Ruminal fermentation and intestinal flow of nutrients by lactating cows consuming brown midrib corn silages. J. Dairy Sci. 84:2469-2477.

Holt, M. S., J.-S. Eun, C. R. Thacker, A. J. Young, X. Dai, and K. E. Nestor Jr.. 2013. Effects of feeding brown midrib corn silage with a high dietary concentration of alfalfa hay on lactational performance of Holstein dairy cows for the first 180 days of lactation. J. Dairy Sci. 96:515-523.

Holt, M. S., C. M. Williams, C. M. Dschaak, J.-S. Eun, and A. J. Young. 2010. Effects of corn silage hybrids and dietary nonforage fiber sources on feed intake, digestibility, ruminal fermentation, and productive performance of lactating Holstein dairy cows. J. Dairy Sci. 93:5397-5407.

James, T., D. Meyer, E. Esparza, E. J. DePeters, and H. Perez-Monti. 1999. Effects of dietary nitrogen manipulation on ammonia volatilization from manure from Holstein heifers. J. Dairy Sci. 82:2430-2439.

Janicek, B. N., P. J. Kononoff, A. M. Gehman, and P. H. Doane. 2008. The effect of feeding dried distillers grains plus solubles on milk production and excretion of urinary purine derivatives. J. Dairy Sci. 91:3544-3553.

Jones, S. J., D. L. Starkey, C. R. Calkins, and J. D. Crouse. 1990. Myofibrillar protein turnover in feed- restricted and realimented beef cattle. J. Anim. Sci. 68:2707-2715.

Jonker, J. S., R. A. Kohn, and R. A. Erdman. 1998. Using milk urea nitrogen to predict nitrogen excretion and utilization efficiency in lactating dairy cows. J. Dairy Sci. 81:2681-2692.

Kung, L., Jr., B. M. Moulder, C. M. Mulrooney, R. S. Teller, and R. J. Schmidt. 2008. The effect of silage cutting height on the nutritive value of a normal corn silage hybrid compared with brown midrib corn silage fed to lactating cows. J. Dairy Sci. 91:1451-1457.

Leonardi, C., M. Stevenson, and L. E. Armento. 2003. Effect of two levels of crude protein and methionine supplementation on performance of dairy cows. J. Dairy Sci. 86:4033-4042.

Littell, R. C., P. R. Henry, and C. B. Ammerman. 1998. Statistical analysis of repeated measures data using SAS procedures. J. Anim. Sci. 76:1216-1231.

Maekawa, M., K. A. Beauchemin, and D. A. Christensen. 2002. Chewing activity, saliva production, and ruminal $\mathrm{pH}$ of primiparous and multiparous lactating dairy cows. J. Dairy Sci. 85:1176-1182.

Martin, N. P., and D. R. Mertens. 2005. Reinventing alfalfa for dairy cattle and novel uses. Pages 299-311 in Proc. California Alfalfa Forage Symp., Visalia, CA. Univ. California, Davis.

Martin, N. P., D. R. Mertens, and P. J. Weimer. 2004. Alfalfa: Hay, haylage, baleage, and other novel products. Pages 9-18 in Proc. Idaho Alfalfa Forage Conf., Twin Falls, ID. Univ. Idaho, Moscow. 
McCarthy, F. D., W. G. Bergen, and D. R. Hawkins. 1983. Muscle protein turnover in cattle of differing genetic backgrounds as measured by urinary $\mathrm{N}^{\prime}$-methylhistidine excretion. J. Nutr. 113:2455-2463.

Mertens, D. R. 2002. Nutritional implications of fiber and carbohydrate characteristics of corn silage and alfalfa hay. Pages $94-107$ in California Anim. Nutr. Conf., Fresno, CA. California State Univ., Fresno.

Nagel, S. A., and G. A. Broderick. 1992. Effect of formic acid or formaldehyde treatment of alfalfa silage on nutrient utilization by dairy cows. J. Dairy Sci. 75:140-154.

Nocek, J. E. 1997. Bovine acidosis: Implications on laminitis. J. Dairy Sci. 80:1005-1028

NRC. 2001. Nutrient Requirements of Dairy Cattle. 7th rev. ed. Natl. Acad. Sci., Washington, DC.

Oba, M., and M. S. Allen. 2000. Effects of brown midrib 3 mutation in corn silage on productivity of dairy cows fed two concentrations of dietary neutral detergent fiber: 3 . Digestibility and microbial efficiency. J. Dairy Sci. 83:1350-1358.

Olmos Colmenero, J. J., and G. A. Broderick. 2006. Effect of dietary crude protein concentration on milk production and nitrogen utilization in lactating dairy cows. J. Dairy Sci. 89:1704-1712.

Penner, G. B., K. A. Beauchemin, and T. Mutsvangwa. 2006. An evaluation of the accuracy and precision of a stand-alone submersible continuous ruminal pH measurement system. J. Dairy Sci. 89:2132-2140.

Ramirez Ramirez, H. A., K. Nestor, L. O. Tedeschi, T. R. Callaway, S. E. Dowd, S. C. Fernando, and P. J. Kononoff. 2012. The effect of brown midrib corn silage and dried distillers' grains with solubles on milk production, nitrogen utilization and microbial community structure in dairy cows. Can. J. Anim. Sci. 92:365-380.

Rhine, E. D., G. K. Sims, R. L. Mulvaney, and E. J. Pratt. 1998. Improving the Bertholot reaction for determining ammonium in soil extracts and water. Soil Sci. Soc. Am. J. 62:473-480.

Russell, J. B., J. D. O'Connor, D. G. Fox, P. J. Van Soest, and C. J. Sniffen. 1992. A net-carbohydrate and protein system for evaluating cattle diets: I. Ruminal fermentation. J. Anim. Sci. 70:35513561

SAS Institute. 2012. SAS/STAT User's Guide. Release 9.3. SAS Institute Inc., Cary, NC.

Shingfield, K. J., and N. W. Offer. 1998. Evaluation of the spot urine sampling technique to assess urinary purine derivate excretion in lactating dairy cows. J. Anim. Sci. 66:557-568.

Shingfield, K. J., and N. W. Offer. 1999. Simultaneous determination of purine metabolites, creatinine, and pseudouridine in ruminant urine by reversed-phase high-performance liquid chromatography. J. Chromatogr. B Biomed. Sci. Appl. 723:81-94.
Smith, L. W., H. K. Goerign, and C. H. Gordon. 1972. Relationships of forage compositions with rates of cell wall digestion and indigestibility of cell walls. J. Dairy Sci. 55:1140-1147.

Tamminga, S. 1996. A review on environmental impacts of nutritional strategies in ruminants. J. Anim. Sci. 74:3112-3124.

Taylor, C. C., and M. S. Allen. 2005a. Corn grain endosperm type and brown midrib 3 corn silage: Site of digestion and ruminal digestion kinetics in lactating cows. J. Dairy Sci. 88:1413-1424.

Taylor, C. C., and M. S. Allen. 2005b. Corn grain endosperm type and brown midrib 3 corn silage: Feeding behavior and milk yield of lactating cows. J. Dairy Sci. 88:1425-1433.

Taylor, C. C., and M. S. Allen. 2005c. Corn grain endosperm type and brown midrib 3 corn silage: Ruminal fermentation and N partitioning in lactating cows. J. Dairy Sci. 88:1434-1442.

Tine, M. A., K. R. McLeod, R. A. Erdman, and R. L. Baldwin VI. 2001. Effects of brown midrib corn silage on the energy balance of dairy cattle. J. Dairy Sci. 84:885-895.

Valadares, R. F. D., G. A. Broderick, S. C. Baladares Filho, and M. K. Clayton. 1999. Effect of replacing alfalfa silage with high moisture corn on ruminal protein synthesis estimated form excretion of total purine derivatives. J. Dairy Sci. 82:2686-2696.

Van Keulen, J., and B. A. Young. 1977. Evaluation of acid-insoluble ash as a natural marker in ruminant digestibility studies. J. Anim. Sci. 44:282-287.

Van Soest, P. J., J. B. Robertson, and B. A. Lewis. 1991. Methods for dietary fiber, neutral detergent fiber, and nonstarch polysaccharides in relation to animal nutrition. J. Dairy Sci. 74:3583-3597.

Wattiaux, M. A., and K. L. Karg. 2004. Protein level for alfalfa and corn silage-based diets: II. Nitrogen balance and manure characteristics. J. Dairy Sci. 87:3492-3502.

Weiss, W. P. 2004. Factors affecting manure excretion by dairy cows. Pages 11-20 in Proc. Cornell Nutr. Conf., Syracuse, NY. Cornell Univ., Ithaca, NY.

Weiss, W. P., L. B. Willett, N. R. St-Pierre, D. C. Borger, T. R. McK elvey, and D. J. Wyatt. 2009. Varying forage type, metabolizable protein concentration, and carbohydrate source affects manure excretion, manure ammonia, and nitrogen metabolism of dairy cows. J. Dairy Sci. 92:5607-5619.

Weiss, W. P., and D. J. Wyatt. 2006. Effect of corn silage hybrid and metabolizable protein supply on nitrogen metabolism of lactating dairy cows. J. Dairy Sci. 89:1644-1653.

Whittet, K. M. 2004. Factors affecting variability in urinary creatinine and purine derivative excretion in beef cattle. MS Diss. University of Nebraska, Lincoln. 